\title{
DETERMINATION OF SOME BIOGENIC AMINES IN RAT PLASMA USING HIGH PERFORMANCE LIQUID CHROMATOGRAPHY TANDEM MASS SPECTROMETRY (HPLC/MS) METHOD
}

\author{
NINA FILIP ${ }^{1 \#}$, CORNELIA MIRCEA $^{2 \#} *$, CRISTINA IANCU ${ }^{2 *}$, MONICA HĂNCIANU $^{2 \#}$, ELENA \\ COJOCARU $^{2 *}$, BOGDAN STOICA $^{1 \#}$, CRISTIANA FILIP $^{1 \#}$ \\ 1 "Grigore T. Popa" University of Medicine and Pharmacy, Faculty of Medicine, 16 University Street, 700115, Iași, Romania \\ 2 "Grigore T. Popa” University of Medicine and Pharmacy, Faculty of Pharmacy, 16 University Street, 700115, Iași, Romania \\ *corresponding author: corneliamircea@yahoo.com \\ \# All authors have equal contribution
}

Manuscript received: July 2017

\begin{abstract}
Biogenic amines are compounds produced by human metabolism which, in small concentrations, exert physiological roles. In high concentrations, biogenic amines can become toxic. In addition to the in vivo generation, biogenic amines result from technological processes for the preparation and preservation of food products. These amines reach the body in concentrations higher than normal, triggering severe side effects. Therefore, quantification of biogenic amines in both food and biological fluids is of major interest. The aim of our study was to optimize and develop a modified HPLC/MS method for the simultaneous separation and quantification of rat plasma histamine, tyramine, cadaverine and putrescine. The proposed method is first applied for the determination of putrescine in rat plasma. The advantage of the method is the possibility of quantifying trace amounts without the time-consuming phase of derivatization.
\end{abstract}

\section{Rezumat}

Aminele biogene sunt produşi ai metabolismul uman care, în concentrații mici, exercită roluri fiziologice. În concentraţii mari, aminele biogene pot deveni toxice. Pe lângă formarea in vivo, aminele biogene rezultă şi prin proceduri tehnologice de preparare și conservare a produselor alimentare. Aceste amine pot ajunge în organism în concentrații mai mari decât valorile normale, declanşând astfel efecte secundare severe. Prin urmare, este importantă determinarea aminelor biogene atât în produsele alimentare cât și în fluidele biologice. Scopul lucrării este de a optimiza şi a aplica o metodă HPLC/MS modificată pentru separarea și cuantificarea simultană a histaminei, tiraminei, cadaverinei și putrescinei din plasma de șobolan. Metoda propusă este aplicată pentru prima dată pentru determinarea putresceinei în plasma de șobolan. Avantajul metodei constă în posibilitatea determinării cantităților foarte mici, fără o etapă prealabilă de derivatizare.

Keywords: histamine, tyramine, cadaverine, putrescine, HPLC/MS, biologic amines

\section{Introduction}

Biogenic amines are compounds produced by the human metabolism [2] and they generate a large number of physiological effects: regulation of the body temperature and blood pressure as well as maintenance of the normal stomach volume. Depending on their concentration, biogenic amines can become very toxic causing even death [3]. Except for the body, biogenic amines are also present in ordinary foodstuffs such as: milk, fish, beer, cheese, chocolate and red wine $[4,16]$. The alteration of proteins, which are present in foodstuffs, as a result of the microorganism's activity, generates biogenic amines. It may also be generated by the technological procedure of foodstuffs preparation or preservation. Ingestion of more than $100 \mathrm{mg}$ of histamine or $100 \mathrm{mg}$ of tyramine can cause intoxications that can trigger a wide range of symptoms ranging from headaches to life-threatening episodes of blood pressure spikes
$[1,6,7]$. Because of their potential toxicity there is an increased interest in the quantification of biogenic amines in booth foodstuffs and biological fluids in order to monitor their concentration. The literature discloses many methods for determining the biogenic amines, such as thin layer chromatography (TLC), gas chromatography (GC), capillary electrophoresis (CE), high performance liquid chromatography (HPLC) and immunological assays [13]. HPLC with pre- or post-column derivatization is the most used method for the separation and the quantification of biogenic amines at the lowest levels $[9,11,14,17$, 18]. In our study we proposed a modified HPLC/MS method for the separation and the quantification of histamine $(\mathrm{H})$, tyramine $(\mathrm{T})$, cadaverine $(\mathrm{C})$ and putrescine $(\mathrm{P})$ from rats plasma starting from the method proposed by Gennaro et al 
$[8,10]$. The proposed method is for the first time applied for putrescine determination in rat plasma.

\section{Materials and Methods}

\section{Reagents and standard solutions}

Cadaverine, histamine, dihydrochloride putrescine, tyramine, formic acid, ammonia (25\%), perchloric acid were acquired from Fluka. Methanol and water Chromasolv (HPLC purity), sodium bisulphite were purchased from Sigma-Aldrich. Standard solutions of biogenic amines, $1 \mathrm{mg} / \mathrm{mL}$ concentration, were prepared in perchloric acid and kept at $-20^{\circ} \mathrm{C}$ for 1 week. Working solutions were prepared by dilution in perchloric acid.

\section{Instruments}

The analyses were performed on an Agilent 1200 HPLC 6520-Accurate-Mass Q Tof LC/MS with Agilent 1200 Binary Pump and C18 column. For pH measurements a $\mathrm{pH}-$ meter Sension 1 was used. An Eppendorf Centrifuge and Ultra-Turrax homogenizer were used for rat plasma preparation.

\section{HPLC-MS conditions}

The stationary phase was a ZORBAX SB C18 column $(150 \times 4.6 \mathrm{~mm}$, particle size $5 \mu \mathrm{m})$. The mobile phase was composed of two solutions: solution A methanol and solution $\mathrm{B}$, a mixture of formic acid and ammonia (15 $\left.\mathrm{mM} \mathrm{NH}_{3}, 15 \mathrm{mM} \mathrm{HCOOH}\right)$ in ultra-pure water, brought to a final $\mathrm{pH}=4$. The mobile phase was eluted under gradient conditions: time $=0 \min 10 \%$ solution A, 90\% solution $\mathrm{B}$; time $=5 \mathrm{~min} 60 \%$ solution $\mathrm{A}, 40 \%$ solution $\mathrm{B}$, at a flow rate of 1 $\mathrm{mL} / \mathrm{min}$. The injection volume was $10 \mu \mathrm{L}$. Mass spectrometer was equipped with an electrospray (ESI) ion source, with nitrogen gas (drying gas) temperature of $325^{\circ} \mathrm{C}$, flow nitrogen gas $7 \mathrm{~L} / \mathrm{min}$, pressure nebulizer gas $30 \mathrm{psi}$, capillary potential $4500 \mathrm{~V}$, capillary temperature $325^{\circ} \mathrm{C}$ and the range $\mathrm{m} / \mathrm{z}$ was $50-300$.

\section{Sample treatment}

The calibration curves for histamine, tyramine, cadaverine and putrescine in plasma were performed using blood from adult Wistar male rats (120 - $200 \mathrm{~g})$. Animals were manipulated according to the standards of the European Legislation for animal in scientific procedure concerning the care and use of experimental animals. All procedures were performed according to the European legislation concerning the care and use of animals for scientific purposes (Directive 86/609/ EEC) and were approved by the Ethics Committee of the "Grigore T. Popa" University of Medicine and Pharmacy Iaşi, Romania (No.15186/2008). Whole blood was collected in vacutainer tubes containing heparin and aliquots of $1 \mathrm{~mL}$ were immediately transferred in glass centrifuge tubes with $0.5 \mathrm{~mL}$ EDTAmetabisulphite solution (20 g EDTA and $10 \mathrm{~g}$ sodium metabisulphite/L) and centrifuged $10 \mathrm{~min}$ at $4000 \mathrm{rpm}$. Half $\mathrm{mL}$ of plasma was removed in Eppendorf tubes which contained $0.5 \mathrm{~mL}$ perchloric acid; allowed to rest for $10 \mathrm{~min}$ and then centrifuged $20 \mathrm{~min}$ at $13000 \mathrm{rpm}$. The supernatant was removed and stored at $-70^{\circ} \mathrm{C}$ until analysed.

Calibration curves

Standard working solutions for the amines, individually and in the mixture, were prepared by dilution in perchloric acid. Standard curves for working solutions having the following concentrations were performed: putrescine 2 - $50 \mathrm{ng} / \mathrm{mL}$ [5], histamine 5 - $100 \mathrm{ng} / \mathrm{mL}$ [12], tyramine [15] $0.5-10 \mathrm{ng} / \mathrm{mL}$ and cadaverine 1 - $20 \mathrm{ng} / \mathrm{mL}$ [5]. Half $\mathrm{mL}$ from each standard solution and from the mixture were added to half $\mathrm{mL}$ of plasma and processed as described above.

\section{Results and Discussion}

Mass spectrum obtained from free (a) and spiked rat plasma with putrescine (b), histamine (c), tyramine (d) and cadaverine (e) respectively are presented in Figure 1 ( $a, b, c, d, e)$.

No detectible signals were found at the $\mathrm{m} / \mathrm{z}$ ratio of the corresponding amine in the free rats' plasma. The retention times for individual amines from the rats' plasma spiked with amine mixture are presented in Figure 2. Individual amines are well separated as they eluted at different retention times: 1.607 for putrescine, 1.639 for histamine, 2.288 for tyramine and 4.248 minutes for cadaverine. The amines mixture was eluted over a period of five minutes which means a reasonable time measurement per sample. The reproducibility for the retention times and for the peak areas was $96.55 \%$ and $92 \%$ respectively.

The calibration curves for individual amines were realized by plotting amines peak areas versus concentrations in $\mathrm{ng} / \mathrm{mL}$. The linear regression equations, coefficient of determination $\left(\mathrm{r}^{2}\right)$, linearity range, detection limits (LOD) and quantification limits (LOQ) for each amine are presented in Table I, 

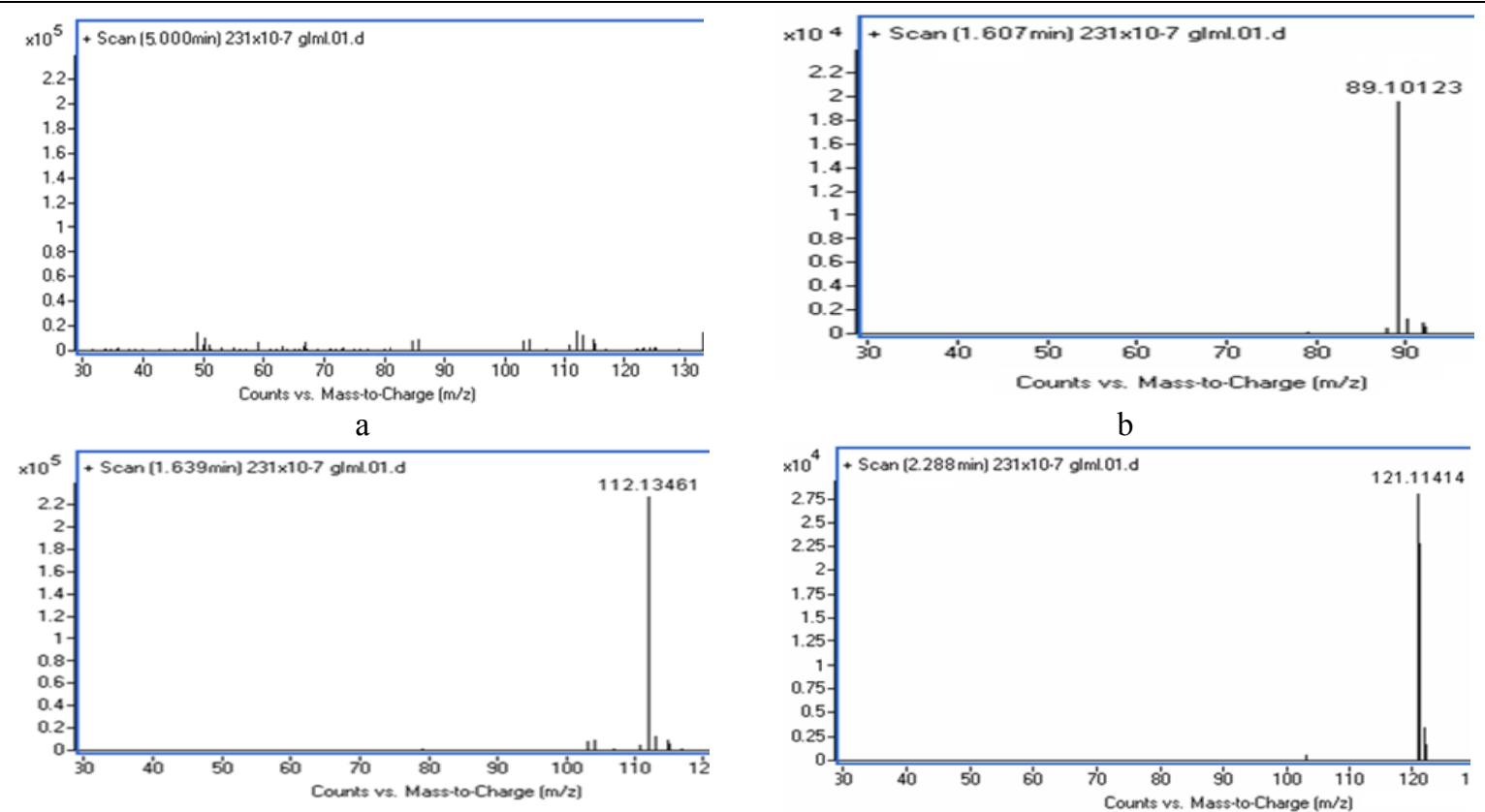

c

d

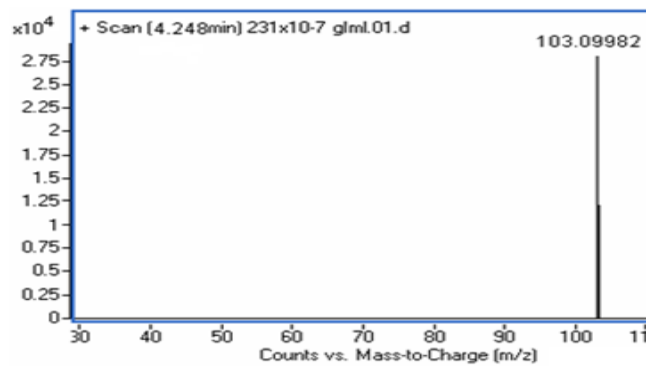

e

Figure 1.

Mass spectrum for free plasma and plasma spiked with biogenic amines

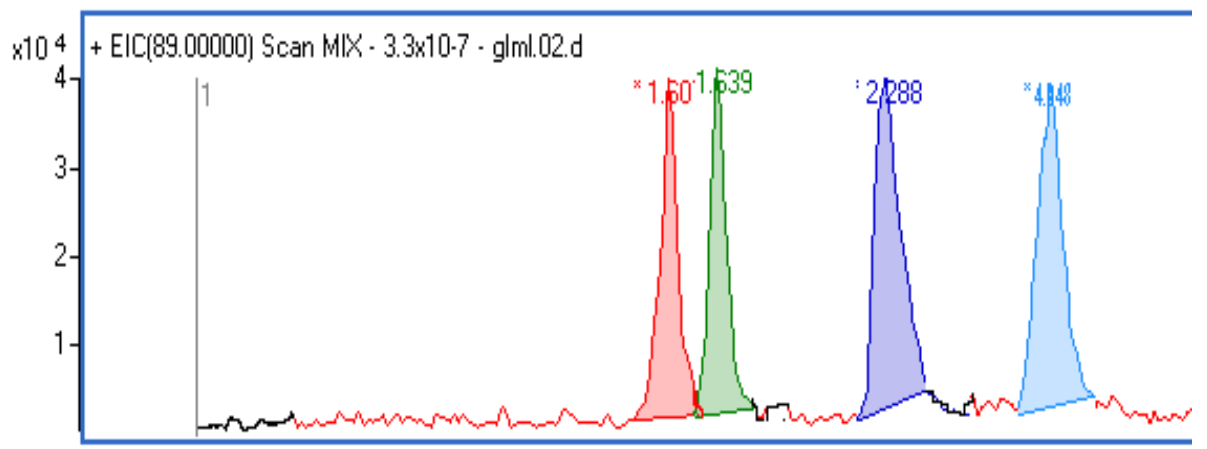

Figure 2.

Chromatogram obtained from rats' plasma spiked with the amine mixture

Table I

The linear regression equations, coefficient of determination $\left(\mathrm{r}^{2}\right)$, linearity range, detection limits (LOD) and quantification limits (LOQ) for individual amines

\begin{tabular}{|c|c|c|c|c|c|c|}
\hline $\begin{array}{c}\text { Eluted } \\
\text { compound }\end{array}$ & $\begin{array}{l}\text { Quantifier transition } \\
(\mathrm{m} / \mathrm{z})\end{array}$ & $\begin{array}{l}\text { Linear regression calibration } \\
\text { curve }\end{array}$ & $r^{2}$ & $\begin{array}{c}\text { Linearity range } \\
(\mathrm{ng} / \mathrm{mL})\end{array}$ & $\begin{array}{c}\text { LOD } \\
(\mathrm{ng} / \mathrm{mL})\end{array}$ & $\begin{array}{c}\text { LOQ } \\
(\mathrm{ng} / \mathrm{mL})\end{array}$ \\
\hline $\mathrm{P}$ & $89-72$ & $y=142.6 x+6546.8$ & 0.9995 & $2-50$ & 1.5 & 2 \\
\hline $\mathrm{H}$ & $112-95$ & $y=870.8 x-4341.6$ & 0.9992 & $5-100$ & 3 & 5 \\
\hline $\mathrm{T}$ & $138-121$ & $y=370.2 x-74.62$ & 0.9985 & $0.5-10$ & 0.2 & 0.5 \\
\hline $\mathrm{C}$ & $103-86$ & $y=28.85 x+8.186$ & 0.9994 & $0.5-20$ & 0.2 & 0.5 \\
\hline
\end{tabular}

$\mathrm{P}=$ putrescine $\mathrm{H}=$ histamine; $\mathrm{T}=$ tyramine $\mathrm{C}=$ cadaverine 
To evaluate the intra-day and inter-days accuracy, precision and recovery $(\mathrm{R})$, the amine mixture was eluted in four replicates for three low, medium and high concentrations added to plasma samples from the standard working solution. The accuracy was expressed as bias\% (relative difference between found and spiked concentration) and precision as $\mathrm{CV} \%$ (coefficient of variation). The intra-day and inter-days runs accuracy, precision and recovery for putrescine, histamine, tyramine and cadaverine are presented in Table II.

Table II

\begin{tabular}{|c|c|c|c|c|c|c|c|c|}
\hline \multirow[b]{2}{*}{$\begin{array}{c}\text { Added } \\
\text { conc. } \\
(\mathrm{ng} / \mathrm{mL})\end{array}$} & \multicolumn{4}{|c|}{ Intra-day runs } & \multicolumn{4}{|c|}{ Inter-days runs } \\
\hline & $\begin{array}{l}\text { Mean found conc. } \\
\quad(\mathrm{ng} / \mathrm{mL} \pm \mathrm{SD})\end{array}$ & $\begin{array}{l}\text { Bias } \\
(\%)\end{array}$ & CV $(\%)$ & $\begin{array}{l}\text { Mean Recovery } \\
\quad(\% \pm \text { SD) }\end{array}$ & $\begin{array}{l}\text { Mean found conc. } \\
\quad(\mathrm{ng} / \mathrm{mL} \pm \mathrm{SD})\end{array}$ & $\begin{array}{l}\text { Bias } \\
(\%)\end{array}$ & CV (\%) & $\begin{array}{c}\text { Mean recovery } \\
(\% \pm \mathrm{SD})\end{array}$ \\
\hline \multicolumn{9}{|c|}{ Putrescine } \\
\hline 2 & $2.1 \pm 0.06$ & 7.1 & 2.8 & $107.1 \pm 3.0$ & $2.17 \pm 0.01$ & 8.8 & 0.8 & $108.8 \pm 0.8$ \\
\hline 5 & $5.2 \pm 0.11$ & 5.0 & 2.1 & $105.1 \pm 2.2$ & $5.31 \pm 0.02$ & 6.2 & 0.4 & $106.3 \pm 0.4$ \\
\hline 50 & $50.6 \pm 0.7$ & 1.5 & 1.4 & $101.5 \pm 1.4$ & $51.7 \pm 0.83$ & 3.4 & 1.6 & $103.4 \pm 1.7$ \\
\hline \multicolumn{9}{|c|}{ Histamine } \\
\hline 5 & $5.2 \pm 0.16$ & 4.9 & 3.2 & $104.9 \pm 3.3$ & $5.3 \pm 0.10$ & 6.8 & 1.9 & $106.8 \pm 2.3$ \\
\hline $\mathbf{5 0}$ & $51.2 \pm 1.12$ & 2.5 & 2.2 & $102.5 \pm 2.2$ & $52.7 \pm 1.9$ & 5.4 & 3.7 & $105.4 \pm 4.5$ \\
\hline 100 & $102.4 \pm 2.3$ & 2.4 & 2.2 & $102.4 \pm 2.3$ & $104.6 \pm 2.7$ & 4.6 & 2.6 & $104.6 \pm 3.1$ \\
\hline \multicolumn{9}{|c|}{ Tyramine } \\
\hline 0.5 & $0.55 \pm 0.01$ & 10.4 & 3.0 & $110.4 \pm 3.4$ & $0.54 \pm 0.04$ & 9.8 & 7.4 & $109.8 \pm 8.2$ \\
\hline 1 & $1.08 \pm 0.02$ & 7.9 & 1.7 & $107.9 \pm 1.8$ & $1.06 \pm 0.02$ & 5.8 & 2.4 & $105.8 \pm 2.6$ \\
\hline 10 & $10.6 \pm 0.17$ & 5.8 & 1.6 & $105.8 \pm 1.7$ & $10.3 \pm 0.17$ & 3.4 & 1.6 & $103.4 \pm 1.7$ \\
\hline \multicolumn{9}{|c|}{ Cadaverine } \\
\hline 1 & $1.07 \pm 0.02$ & 7.8 & 2.2 & $107.8 \pm 2.4$ & $1.10 \pm 0.03$ & 10.5 & 2.3 & $110.5 \pm 2.5$ \\
\hline 10 & $10.39 \pm 0.2$ & 4.0 & 1.8 & $103.9 \pm 1.9$ & $10.75 \pm 0.3$ & 7.5 & 3.2 & $107.5 \pm 3.5$ \\
\hline 20 & $20.60 \pm 0.8$ & 3.0 & 3.7 & $103.0 \pm 3.9$ & $21.39 \pm 0.6$ & 7.0 & 2.7 & $107.0 \pm 2.9$ \\
\hline
\end{tabular}

We used the above method to determine the levels of biogenic amines either in processed meat products [19] or in biological samples. We administered biogenic amines in rats and correlated them to the activities of the antioxidant enzymes (glutathione peroxidase and superoxide dismutase) and to the total antioxidant status. The HPLC/MS method allowed us to detect high levels of biogenic amines, particularly histamine, 72 hours after administration [20]. The determined 72-hour levels of biogenic amines decreased the total antioxidative status in rat plasma and reduced the capacity of the antioxidant enzymes defence system. [20]

\section{Conclusions}

The analytical determination of biogenic amines presents a real interest because they are involved in numerous diseases. The proposed method is applied to simultaneously determinate histamine, cadaverine, tyramine and putrescine in rat plasma. The proposed HPLC/MS method for the separation and quantification of histamine, tyramine, cadaverine and putrescine from plasma eliminates the timeconsuming derivatization step. This technique offers a significant advantage because retention times are reduced compared to other analytical methods used for the determination of the biogenic amines. Thus, this method requires a reasonable amount of time per analysis.

\section{References}

1. Albu E, Lupascu D, Filip C, Jaba IM, Zamosteanu N, The influence of a new rutin derivative on homocysteine, cholesterol and total antioxidatwe status in experimental diabetes in rat. Farmacia, 2013; 61(6): 1167-1177.

2. Baixas NS, Bover S, Veciana-Nogues MT, Vidal-Carou MC, Amino acid-decarboxylase activity in bacteria associated with Mediterranean hake spoilage. Eur Food Res Technol., 2003; 217: 164-167.

3. Bedry R, Gabinski C, Paty MC, Diagnosis of scombroid poisoning by measurement of plasma histamine. New Eng J Med., 2000; 342: 520-521.

4. Biji KB, Ravishankar CN, Venkatewarlu R, Mohan $\mathrm{CO}$, Gopal TK, Biogenic amines in seafood: a review. J. Food Sci Technol., 2016; 53(5): 2210-2218.

5. Desser G, Kleinberger K, Klaring J, Plasma polyamine levels in liver insufficiency. J Clin Chem Clin Biochem., 1981; 19: 159-164.

6. Eerola HS, Roig-Sagues AX, Hirvi TK, Biogenic amines in finish dry sausages Journal of Food Safety, 1998; 18: 127-138.

7. Filip C, Albu E, Lupascu D, Filip N, The influence of a new rutin derivative in an experimental model of induced hyperhomocysteinemia in rats. Farmacia, 2017; 65(4): 596-599.

8. Gosetti F, Mazzucco E, Gianotti V, Polati S, Gennaro $\mathrm{MC}$, High performance liquid chromatography/tandem mass spectrometry determination of biogenic amines in typical Piedmont cheeses. $J$ Chromatography A, 2007; 1149(2): 151-157.

9. Gosetti F, Mazzucco E, Gennaro MC, Marengo E, Simultaneous determination of sixteen underivatized 

biogenic amines in human urine by HPLC-MS/MS.
Anal Bioanal Chem., 2013; 405(2-3): 907-916.

10. Gianotti V, Chiuminatto U, Mazzucco E, Gosetti F, Bottaro M, Frascarolo P, Gennaro MC, A new hydrophilic interaction liquid chromatography tandem mass spectrometry method for the simultaneous determination of seven biogenic amines in cheese. $J$ Chromatogr A, 2008; 1185: 296-300.

11. He Y, Zhao XE, Wang R, Wei N, Sun J, Dang J, Chen G, Liu Z, Simultaneous determination of foodrelated biogenic amines and precursor aminoacids using in situ derivatization ultrasound-assisted dispersive liquid-liquid microextraction by ultra-high-performanceliquid chromatography tandem mass spectrometry. J Agric Food Chem., 2016; 64(43): 8225-8234.

12. Jackson JA, Riordan HD, Neathery S, Revard C, Histamine levels in health and disease. Journal of Orthomolecular Medicine, 1998; 13(4): 236-240.

13. Lange J, Thomas K, Wittmann C, Comparison of a capillary electrophoresis method with high-performance liquid chromatography for the determination of biogenic amines in various food samples. $J$ Chromatogr $B$, 2002; 779: 229-239.

14. Laurichesse $\mathrm{M}$, Gicquel $\mathrm{T}$, Moreau $\mathrm{C}$, Tribut $\mathrm{O}$, Tarte K, Morel I, Bendavid C, Amé-Thomas P, Histamine quantification in human plasma using high resolution accurate mass LC-MS technology. Clinical Biochemistry, 2016; 49(1): 111-116.

15. Lentner C, West Cadwell NJ, Geigy Scientific Tables. Medical Education Div., Ciba-Geigy Corp, Basel, 1984-1992, 165-177.

16. Skypala IJ, Williams M, Reeves L, Meyer R, Venter C, Sensitivity to food additives, vaso-active amines and salicylates: a review of the evidence. Clinical and Translational Allergy, 2015; 5: 1-11.

17. Sentellas S, Nunez O, Saurina J, Recent advances in the determination of biogenic amines in food samples by (U)HPLC. J Agric Food Chem., 2016; 64(41): 7667-7678.

18. Xiong X, Zhai S, Rapid and simultaneous quantification of polyamines in human plasma by LC-MS/MS after pre-column derivatization with $\mathrm{N}$-(9-fluorenylmethoxycarbonyloxy) succinimide. Chromatographia, 2016; 79(9-10): 561-570.

19. Zamosteanu N, Filip C, Jerca L, Albut I, Cuciureanu R, Biogenic amines determination in some Romanian meat products. Rev Med Chir Soc Med Nat Iasi, 2009; 113(4): 1195-1199.

20. Zamosteanu N, Filip C, Albu E, Ungureanu D, Cuciureanu R, Total antioxidant status in the blood serum of rats after biogenic amines administration. Rev Med Chir Soc Med Nat Iasi, 2009; 113(2): 502-504. 